Article

\title{
The Variability of Mercury Content in Bituminous Coal Seams in the Coal Basins in Poland
}

\author{
Justyna Auguścik-Górajek * D and Marek Nieć \\ Mineral and Energy Economy Research Institute, Polish Academy of Sciences, J. Wybickiego 7a str., \\ 31-261 Cracow, Poland; niecm@wp.pl \\ * Correspondence: auguscik@meeri.pl; Tel.: +48-12-617-16-45
}

Received: 2 September 2020; Accepted: 27 October 2020; Published: 30 October 2020

\begin{abstract}
The mercury content in bituminous coal in Poland varies depending on the coal basin. The highest of its concentrations are recorded in the Lower Silesian Coal Basin where this may be the result of the volcanic activity reported there. A much lower average of $\mathrm{Hg}$ content was recorded in Lublin and the Upper Silesian Coal Basins (LCB and USCB), although it was higher in the former. A higher mercury concentration in the LCB is probably related to the zone of supposed deep disturbances, named the Karpinsky lineament. Most published works present the data on the mercury content in the bulk of mined coal. The preliminary assessment of mercury content in coal seams indicates that it varies considerably between and within them. It is bound to the presence of arsenic-bearing iron sulfides. Concentration of mercury in small zones of limited extent suggests it was introduced by migrating fluids. The knowledge of mercury content distribution in coal seams would improve the prediction of its content in the mined coal and allow better management of produced coal quality with the aim of reducing mercury emission to the atmosphere as a result of coal combustion.
\end{abstract}

Keywords: mercury; bituminous coal; Lublin Coal Basin; Upper Silesian Coal Basin; Lower Silesian Coal Basin

\section{Introduction}

Mercury is a poisonous element with high chemical and biochemical activity. It is a natural component of coal that is released during its combustion. This is one of the major sources of $\mathrm{Hg}$ emission into the atmosphere [1-3]. The main problem is the ability of its compounds for phase transformation, persistence in the atmosphere for long periods and mobility over long distances [4].

Most researchers focus on average mercury concentration in the delivered coal. The detailed information on the source of coal is either not provided or very general. This can lead to erroneous conclusions regarding the sources of atmospheric pollution and hinder the reduction of emissions. An example are the data on mercury content in bituminous coal imported to the Netherlands, including that from Poland, presented by R. Meij and B.H. te Winkel [5]. These data suggest incorrectly that Polish bituminous coal is characterized by a very high $\mathrm{Hg}$ content $(0.33 \mathrm{mg} / \mathrm{kg})$, two to six times higher than that delivered from other countries.

The previous research is mostly focused on mercury content in mined coal [4,6-18]. As a rule, the data on average concentrations in coal from the whole coal basin or from individual mines are given. Overly general information on the source of coal may lead to misconceptions about its real quality.

The detailed study on the mode of $\mathrm{Hg}$ occurrence in coal, factors influencing its distribution and origin was presented by Yudovich and Ketris [3,19], however the results of the detailed study of mercury content in particular coal seams are seldom reported. Mastalerz and Drobniak [20] have studied the coal seams in Indiana and demonstrated varied mercury content in the different sampling 
sites and in the seam vertical section. The aim of the present paper is to point out, using an example of coal deposits in Poland, the importance of a more detailed such study of mercury content in coal, which varies not only among and within coal basins, but also within particular coal seams.

\section{Mercury Content in the Polish Coals}

The bituminous coal deposits in Poland occur in the three coal basins (Figure 1): Upper Silesian (USCB), Lublin (LCB), and Lower Silesian (LSCB). They differ greatly in mercury content (Figure 2).

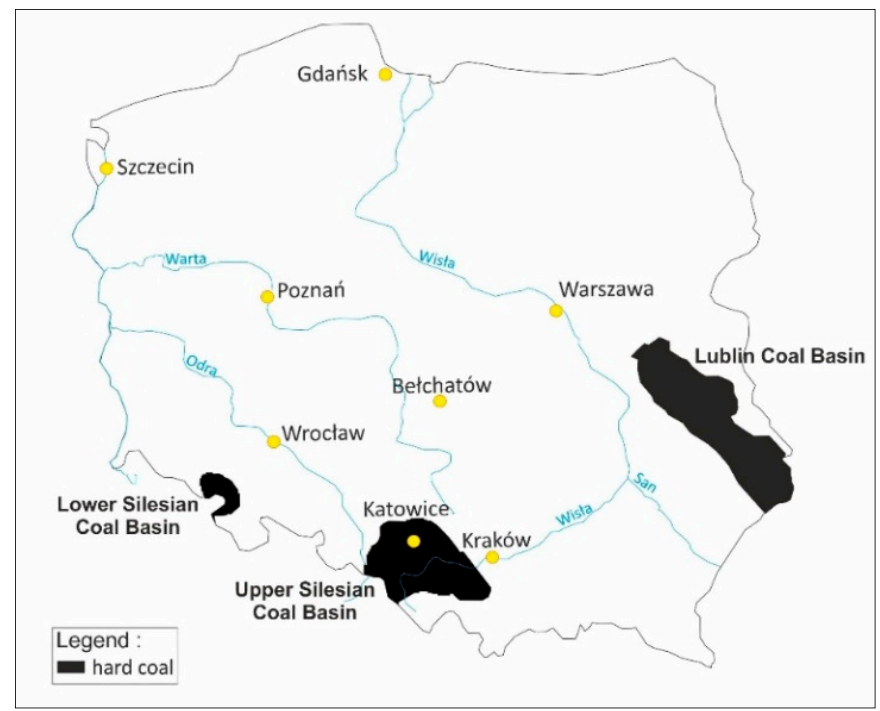

Figure 1. Coal basins in Poland.

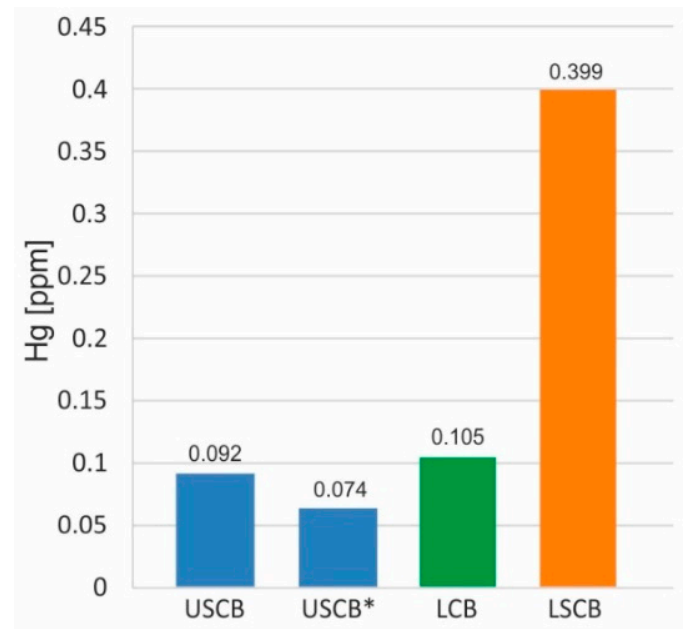

Figure 2. Average mercury content in the hard coal from Poland deposit (USCB-Upper Silesian Coal Basin, LCB_Lublin Coal Basin, LSCB_Lower Silesian Coal Basin). Source: USCB [4,6-9]; USCB* [21]; LCB [7]; LSCB [6].

The highest concentrations of this element can be found in the Lower Silesian Coal Basin (where the average $\mathrm{Hg}$ content in bituminous coal for the Nowa Ruda mine was 0.339 ppm [6]. A much lower average $\mathrm{Hg}$ content was recorded for both the LCB and USCB coal basin but in the LCB, it is higher than in the USCB (Figures 2 and 3).

The data on the mercury content in bituminous coal imported from Poland to the Netherlands presented by R. Meij and B.H. te Winkel [5] probably refer to high quality coal from the Lower Silesian Coal Basin. 


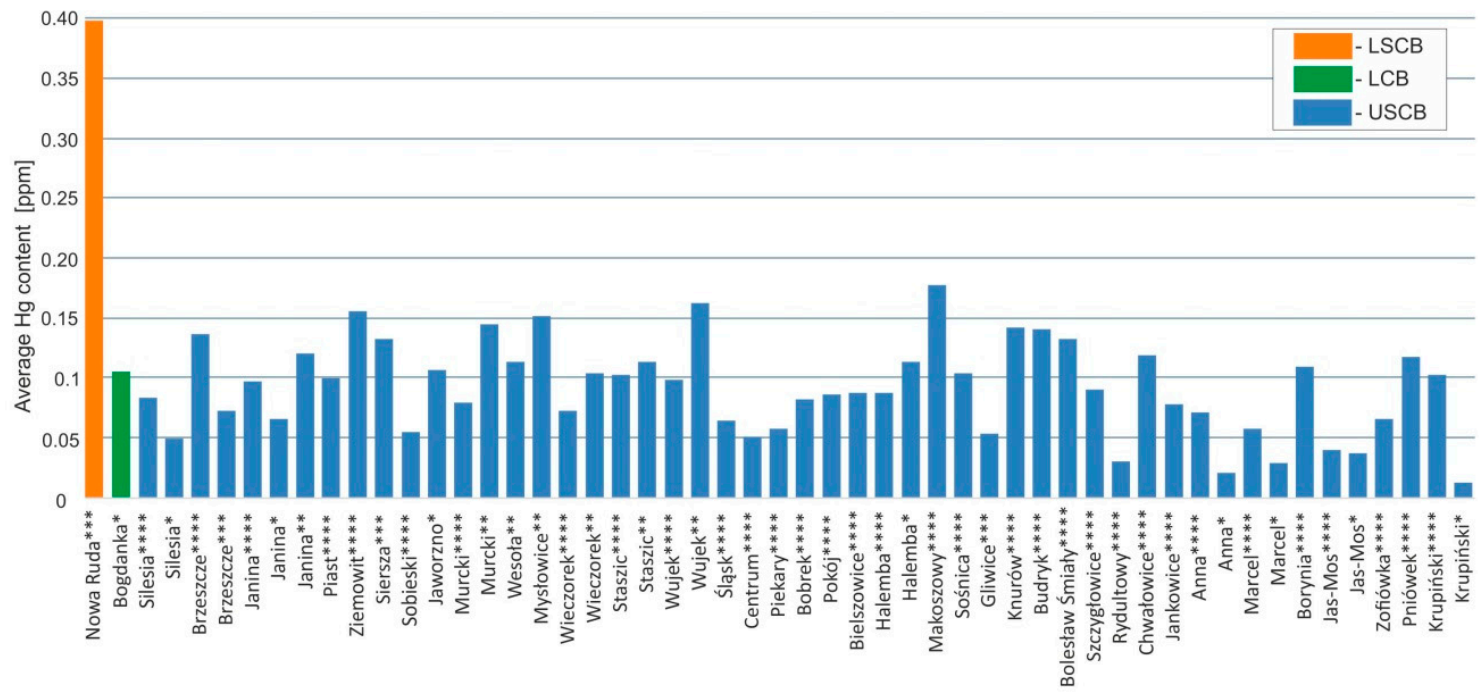

Figure 3. Average mercury content in the hard coal from individual mines in Poland (USCB-Upper Silesian Coal Basin, LCB_Lublin Coal Basin, LSCB_Lower Silesian Coal Basin). Source: * [7,8]; ** [9]; $* * *[6] ; * * * *[4]$.

In the Upper Silesian Coal Basin, Klojzy-Karczmarczyk and Mazurek [21] have demonstrated that mercury content in coal varies considerably among particular studied mines (Figure 3). Any rules of such variation, and the dependence of their stratigraphic position was not noticed, maybe due to the insufficient number of samples analyzed.

Wierzchowski et al. [22] have studied the mercury content in the coal seams grouped according to their stratigraphic position. They found that mercury content in ash-free coal is low. It shows a tendency to decrease with the seams age. The increased mercury content can only be found locally.

The insufficient data on the mercury content in individual coal seams make it difficult to predict the mercury content in the mined bulk coal. Without such knowledge, the management of Hg content in the exploited coal and the attempts to keep it within the acceptable limits, as well as the prediction of its emission to the atmosphere, as a result of coal combustion is impossible.

The problems of mercury content assessment in bituminous coal are presented by the pilot studies carried out, with the aim of determination of its content variation in relation to the location within the coal seam and barren partings.

\section{Materials and Methods}

The mercury content was studied in the three coal seams named: A, B, C, located within the Upper Baschkirian coal bearing series in one of coal mines (Figure 4). The mine owner did not allow the mine location to be disclosed, but this is irrelevant for the aim of the present study.

In each of the studied coal seams, the samples of $20-25 \mathrm{~cm}$ vertical length and about $2 \mathrm{~kg}$ weight were cut separately in coal and in barren partings. Their location was varied (Figure 5):

- Seam "A" in two locations separated by a 10-m distance, in the bottom part where clarain coal occurs and in barren partings of claystone, coal laminated;

- Seam "B" in two locations separated by a 22-m distance, in the bottom, middle and upper part formed by vitrain and clarain coal, respectively;

- Seam " $C$ " in the central part built of vitrain coal and in the bottom part of vitrain coal with iron sulfide in the cleats.

The samples were crushed to a 2-mm grain size and afterwards $250 \mathrm{~g}$ was pulverized to analytical size. The chemical analyses were carried out at the Acme Analytical Laboratories, Canada by ICP Mass Spectroscopy according to the AQ251-EXT standard procedure with a $0.005 \mathrm{ppm} \mathrm{Hg}$ 
detection limit. Ten samples of coal and two samples of gangue partings from the examined seams (A, B, and C) were analyzed. The results were presented with the use of classical statistical methods: evaluation of basic distribution measures and graphically by the box-and-whiskers plot. The varied models of distribution were tested and the best fitting empirical data were verified through the Kołmogorov-Smirnov and Shapiro-Wilk tests.

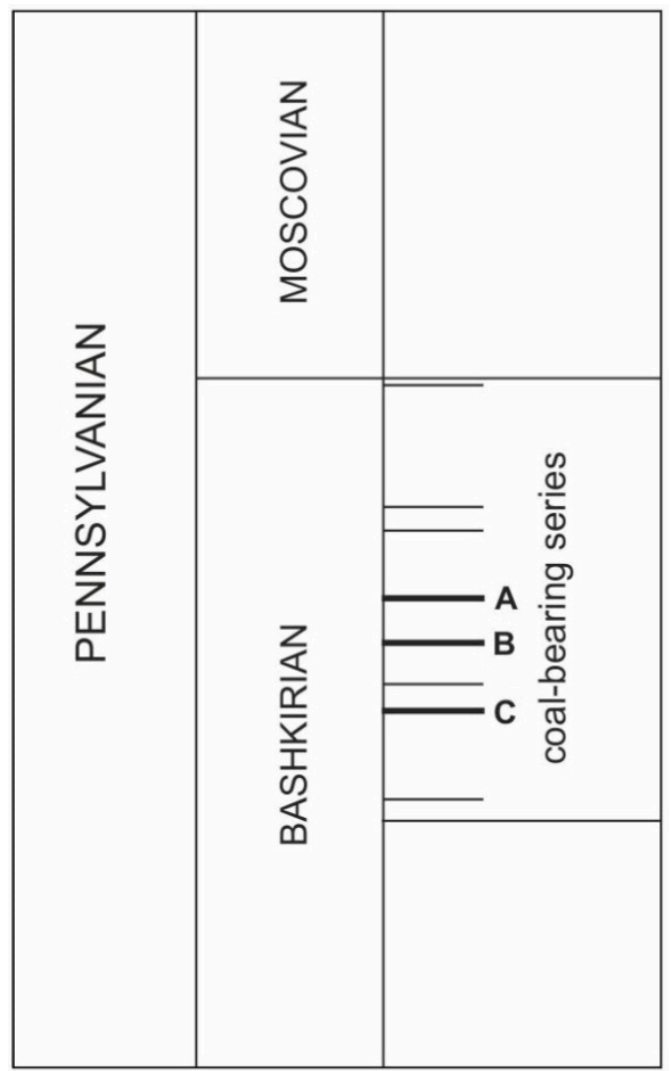

Figure 4. Localization of studied coal seams within coal B series (only the main coal seams are presented). The maximum thickness of the coal bearing series is $400 \mathrm{~m}$.
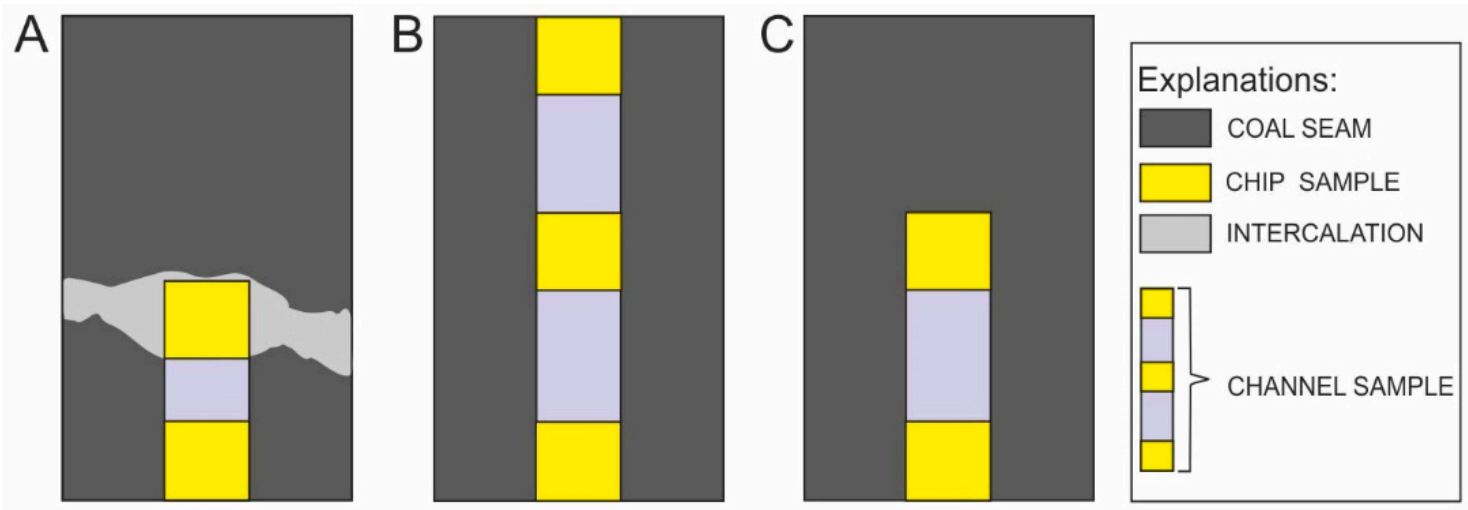

Figure 5. A sampling scheme in seams A, B and C.

The enrichment factors of mercury content in relation to Clarke values were calculated according to this formula [23]:

$$
\begin{aligned}
& \mathrm{EF}^{*}=\frac{\mathrm{p}_{\mathrm{i}}}{\mathrm{o}_{\mathrm{i}}}[-] \\
& \mathrm{EF}^{* *}=\frac{\mathrm{s}_{\mathrm{i}}}{\mathrm{o}_{\mathrm{i}}}[-]
\end{aligned}
$$


where: $p_{i}$ - the average content of a given element in bituminous coal samples from studied coal seams), $\mathrm{s}_{\mathrm{i}}$ - the average content of mercury in bituminous coal worldwide, according to Ketris, Yudovich [24], $\mathrm{o}_{\mathrm{i}}$ - the Clarke value for sedimentary rocks.

Explanations: The mercury enrichment factor in the studied area $\left(\mathrm{EF}^{*}\right)$ and worldwide bituminous coals $\left(\mathrm{EF}^{* *}\right)$.

\section{Results}

The Hg content in the analyzed coal samples varies considerably (Figure 6, Table 1). The average in the studied area is $0.140 \mathrm{ppm}$ and is slightly higher than average reported by Bojakowska and Sokołowska [7].

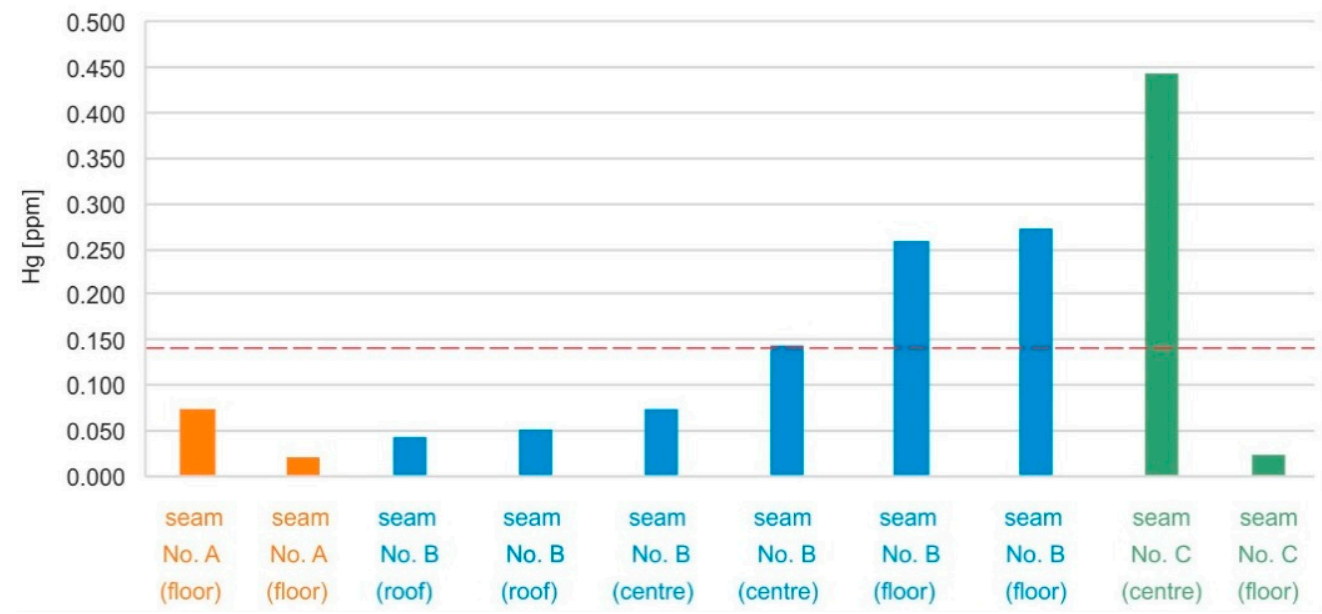

Figure 6. The content of $\mathrm{Hg}$ in coal seams A, B, and C (red dashed line-average content of $\mathrm{Hg}$ in the studied area).

Table 1. The Hg, S, As content in coal from seams A, B, and C and basic statistical parameters.

\begin{tabular}{ccccccccccc}
\hline \multicolumn{10}{c}{ Coal Seam and Sample Location } \\
\hline Element & $\begin{array}{c}\text { A } \\
\text { Bottom } \\
\text { Part }\end{array}$ & $\begin{array}{c}\text { A } \\
\text { Bottom } \\
\text { Part }\end{array}$ & $\begin{array}{c}\text { B } \\
\text { Upper } \\
\text { Part }\end{array}$ & $\begin{array}{c}\text { B } \\
\text { Upper } \\
\text { Part }\end{array}$ & $\begin{array}{c}\text { B } \\
\text { Bottom } \\
\text { Part }\end{array}$ & $\begin{array}{c}\text { B } \\
\text { Upper } \\
\text { Part }\end{array}$ & $\begin{array}{c}\text { B } \\
\text { Central } \\
\text { Part }\end{array}$ & $\begin{array}{c}\text { B } \\
\text { Bottom } \\
\text { Part }\end{array}$ & $\begin{array}{c}\text { C } \\
\text { Part }\end{array}$ & $\begin{array}{c}\text { C } \\
\text { Bottom } \\
\text { Part }\end{array}$ \\
\hline $\begin{array}{c}\text { Hg } \\
(\mathrm{ppm})\end{array}$ & 0.074 & 0.02 & 0.043 & 0.143 & 0.259 & 0.051 & 0.075 & 0.272 & 0.445 & 0.022 \\
\hline $\mathrm{S}(\mathrm{ppm})$ & 3000 & 3400 & 5900 & 8300 & 18,400 & 5100 & 5900 & 15,000 & 20,100 & 3500 \\
\hline $\begin{array}{c}\text { As } \\
(\mathrm{ppm})\end{array}$ & 0.7 & 0.9 & 4.2 & 2.6 & 46.1 & 4.7 & 1.2 & 19.4 & 37.7 & 0.7 \\
\hline $\begin{array}{c}\text { Element } \\
\text { Number }\end{array}$ & Average & Median & $\begin{array}{c}\text { Standard } \\
\text { Deviation }\end{array}$ & $\begin{array}{c}\text { Variation } \\
\text { Coefficient }\end{array}$ & Min. & Max. \\
\hline $\begin{array}{c}\text { Hg } \\
(\mathrm{ppm})\end{array}$ & 10 & 0.140 & 0.075 & 0.141 & $100.4 \%$ & 0.020 & 0.445 \\
\hline S (ppm) & 10 & 0.886 & 0.590 & 0.650 & $73.3 \%$ & 0.300 & 2.010 \\
\hline $\begin{array}{c}\text { As } \\
(\mathrm{ppm})\end{array}$ & 10 & 11.82 & 3.40 & 16.912 & $142.1 \%$ & 0.70 & 46.10 \\
\hline
\end{tabular}

The calculated basic statistical parameters of mercury content are presented in Table 1 . The probability distribution of $\mathrm{Hg}$ content is characterized by a moderate asymmetry. On the box and whiskers plot, no outliers and anomalous high values for the $\mathrm{Hg}$ have been registered (Figure 7). The Birnbaum-Saunders distribution is the best in describing the observed mercury content empirical data (Figure 8). 


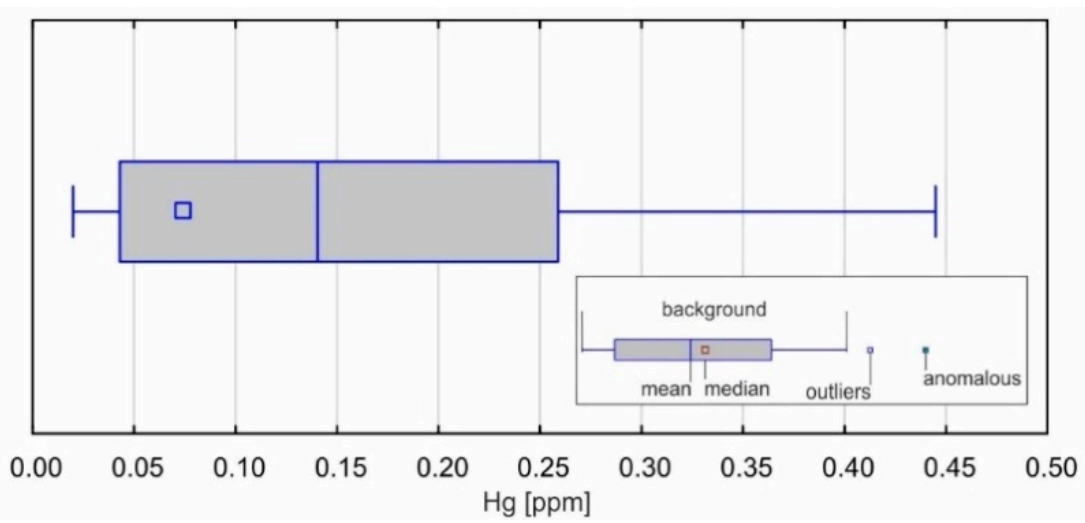

Figure 7. A box-and-whiskers plot diagram for mercury $(\mathrm{Hg})$.

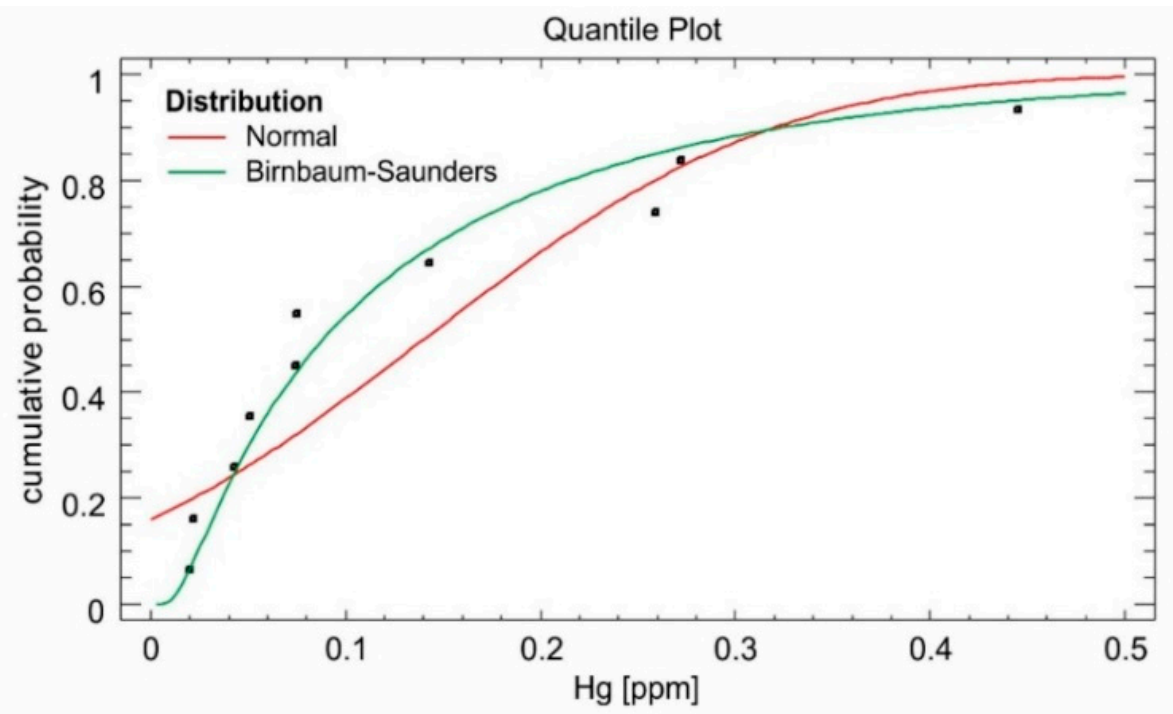

Figure 8. Quantile plots of probability distribution for $\mathrm{Hg}$.

The analytical data on $\mathrm{Hg}$ content in samples of barren partings in the bituminous coal seam have shown their great difference, while the sampling sites are located at a 10-m distance only (Table 2). In sample 2, this is comparable with that observed in the coal, while in sample 1 it is very high (fourteen times higher). Such data show that the elevated concentrations of mercury occur in small zones of limited extent.

Table 2. The mercury content in the barren parting in seam A.

\begin{tabular}{ccc}
\hline Sample & Sample 1 & Sample 2 \\
\hline $\mathrm{Hg}(\mathrm{ppm})$ & 0.649 & 0.045 \\
$\mathrm{~S}(\%)$ & 2.20 & 0.12 \\
$\mathrm{As}(\mathrm{ppm})$ & 10.50 & 1.20 \\
\hline
\end{tabular}

In the studied coal there is clear relationship between mercury and sulfur, as well as arsenic content (Figure 9). It suggests that mercury bearing might be iron sulfides. However, the presence of visible iron sulfide is not followed by outstanding $\mathrm{Hg}$ content. 

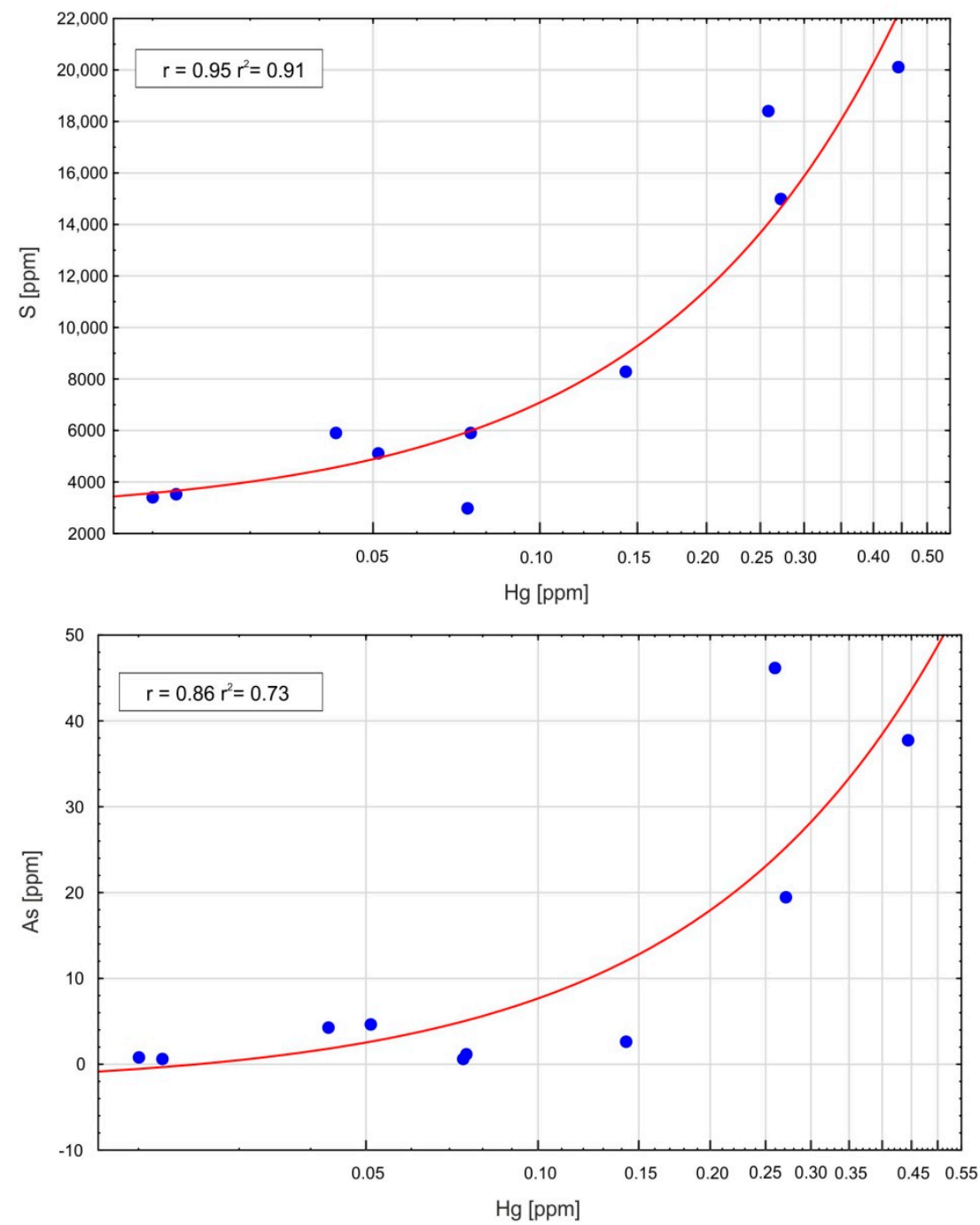

Figure 9. $\mathrm{Hg}$, $\mathrm{S}$ and As content correlation in studied coals. Explanations: $\mathrm{r}$ - the correlation coefficient, $\mathrm{r}^{2}$ - the coefficient of determination.

\section{Discussion}

The existing up-to-date data on mercury content in coal in Poland demonstrate that it varies depending on the coal basin. The average Hg content in the USCB is lower than in the LCB and LSCB. The increased mercury content in the LSCB may be related to the hydrothermal mineralization accompanying younger volcanic activity and intrusions of igneous rocks $[25,26]$. Elevated mercury concentration in the LCB is probably related to the location in the zone of deep disturbances, commonly referred to as the Karpinsky lineament. The Donets Coal Basin in Ukraine with Nikitowka mercury ore deposit [27] is located in this zone. Elevated $\mathrm{Hg}$ content is reported in the same zone within the territory of Poland in the lignite Bełchatów deposit [28] and in natural gases in the north-west Polish lowlands [29] (Figure 10) [30].

The average $\mathrm{Hg}$ content in bituminous coals from the studied area is higher than other coals worldwide and other sedimentary rocks [24]. This is also well presented by the appropriate enrichment factors (Figure 11).

The present study demonstrates great variation of mercury content within individual seams. They also suggest the association of mercury with iron sulfides (arsenic-bearing). 

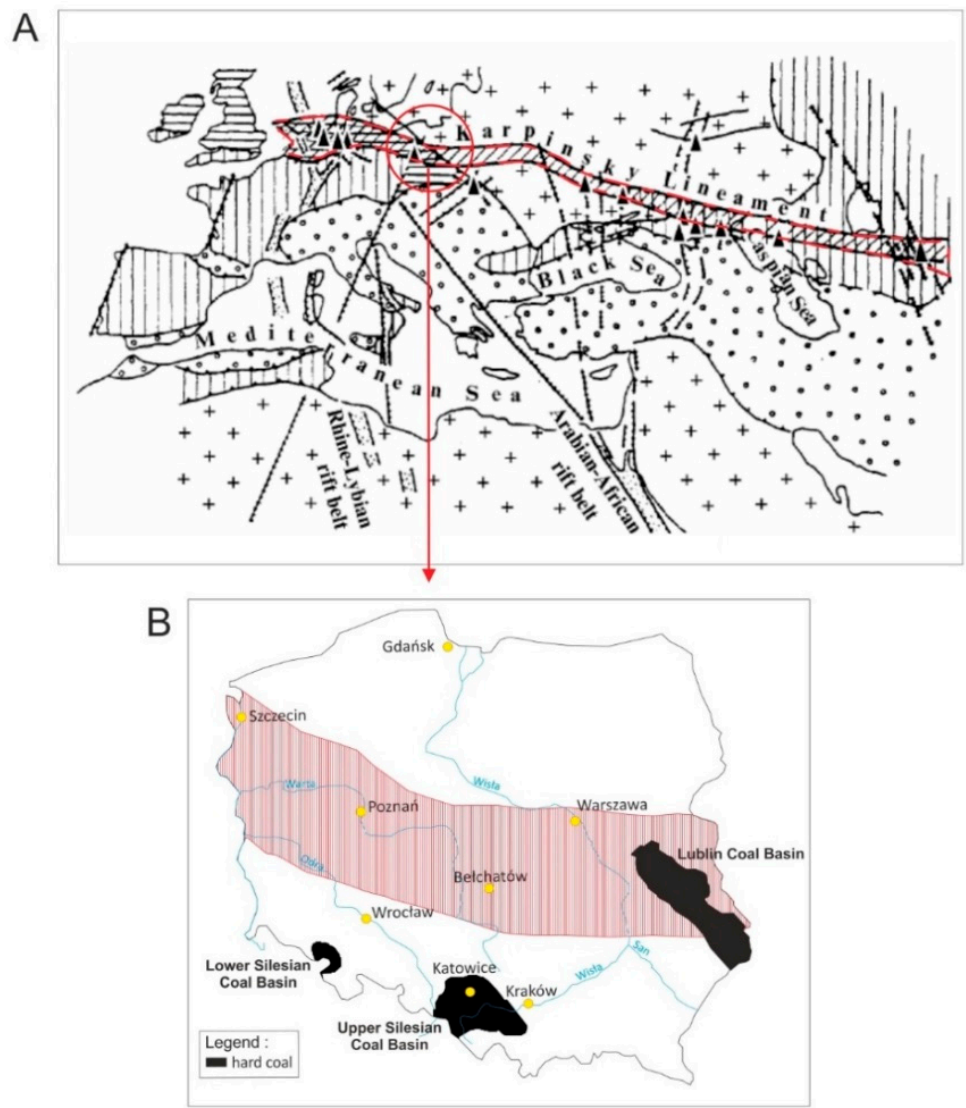

Figure 10. Karpinsky lineament (hatched line) according to Ozerova 29 traced by the location of the mercury-bearing gas and oil-gas deposits (A), approximate trend of the elevated mercury $(\mathrm{Hg})$ concentrations zone in Poland (B).
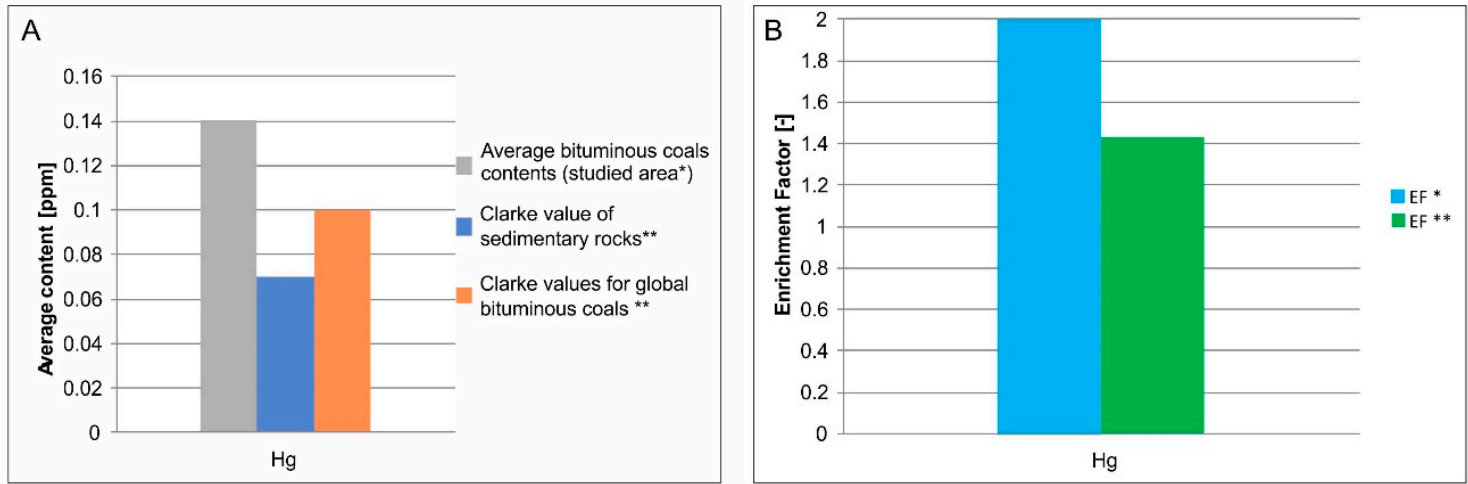

Figure 11. The comparison of the average concentration of mercury in bituminous coal from the studied area* and the Clarke values [24] (A), the mercury enrichment factor in the studied area (EF*) and worldwide bituminous coals $\left(\mathrm{EF}^{* *}\right)(\mathbf{B})$.

The association of mercury content in coal with the presence of iron sulfides, is common [21,31-33]. Such a relationship was also suggested by Dziok et al. $[34,35]$ based on analytical data of coking coal and coal ash. The elevated mercury content associated with pyrite, often arsenic-bearing, allows the supposition of their epigenetic formation by migrating fluids, and the distance to their source $[21,36]$. The barren partings look favorable for mercury concentration.

Very high variability coefficient of mercury content in the studied coal, close to $100 \%$ advocates for its local enrichment sites. The nature of elevated mercury content is enigmatic. Some relation to tectonic phenomena may be supposed. The fault zones may be the site of its concentration, especially 
if some hydrothermal processes were possible [3,20]. The elevated $\mathrm{Hg}$ content close to fault zones, as well as the other metallic elements were suggested in the LCB [37]; there, the deep sited sources of mercury and migration of hydrothermal metamorphic fluids may be admitted, as the basin is located in the zone of supposed Karpinski lineament.

\section{Conclusions}

Numerous studies were devoted to studying the mercury content and the mode of occurrence in coal. Much effort is spent for reducing its emission into the atmosphere as a result of coal combustion. Varied modes of its removal are proposed [38]. In the present study, we try to demonstrate the variation of mercury content among and within the particular coal seams. The detailed "in situ" coal sampling might allow the detection of mercury-enriched zones. It is supposed that such zones may be tectonically controlled.

The knowledge of mercury content distribution within coal seams would allow for better prediction and management of mined coal quality. The possibility of avoiding mercury-enriched coal extraction should be considered in the discussion on the mode of reduction the environmental impact of mercury emission.

Author Contributions: All authors contributed to the development of the current paper. The concept and methodology were prepared by J.A.-G., while the detailed literature review, discussion and recommendations have been done by J.A.-G. and M.N. The revision (review and editing) of the proposed literature review, discussion and recommendations have been done by J.A.-G. and M.N. All authors have read and agreed to the published version of the manuscript.

Funding: This research was financed from the statutory subsidy of the Mineral and Energy Economy Research Institute, Polish Academy of Sciences.

Conflicts of Interest: The authors declare no conflict of interest.

\section{References}

1. Zhao, S.; Pudasainee, D.; Duan, Y.-F.; Gupta, R.; Liu, M.; Lu, J. A review on mercury in coal combustion process: Content and occurrence forms in coal, transformation, sampling methods, emission and control technologies. Prog. Energy Combust. Sci. 2019, 73, 26-64. [CrossRef]

2. Kolker, A.; Senior, C.L.; Quick, J.C. Mercury in coal and the impact of coal quality on mercury emissions from combustion systems. Appl. Geochem. 2006, 21, 1821-1836. [CrossRef]

3. Yudovich, Y.E.; Ketris, M.P. Rtut' w uglach—Serieznaya ekologicheskaya problema. Biosfera 2009, 1, $237-247$.

4. Michalska, A.; Białecka, B. Zawartość rtęci w węglu i odpadach górniczych. Pr. Nauk. GIG Górnictwo Środowisko 2012, 3, 73-87.

5. Meij, R.; Winkel, B.H. Trace elements in world steam coal and their behavior in Dutch coal-fired power stations-A review. Int. J. Coal Geol. 2009, 77, 289-293. [CrossRef]

6. Olkuski, T. Porównanie zawartości rtęci w węglach polskich i amerykańskich. Polityka Energetyczna 2007, 10, 603-611.

7. Bojakowska, I.; Sokołowska, G. Rtęć w kopalinach wydobywanych w Polsce jako potencjalne źródło zanieczyszczeń środowiska. Biuletyn PIG 2001, 394, 5-54.

8. Smoliński, A. Energetyczne wykorzystanie węgla źródłem emisji rtęci-Porównanie zawartości tego pierwiastka w weglach. Ochr. Powietrza Probl. Odpadów 2007, 41, 45-53.

9. Pajdak, A.; Łuczkowska, D.; Walawska, B. Assessment of the possibilities of passive mercury removal in dry flue gas cleaning with sodium reagents. ZZesz. Nauk. Inst. Gospod. Surowcami Miner. Energia PAN 2017, 97, 95-106.

10. Bojakowska, I.; Szczęśniak, H. Zagrożenie naturalnego środowiska w Polsce rtęcia w wyniku spalania węgli. Przegląd Geol. 1993, 4, 252-257.

11. Goodarzi, F. Assessment of elemental content of milled coal, combustion residues, and stack emitted materials: Possible environmental effects for a Canadian pulverized coal-fired power plant. Int. J. Coal Geol. 2006, 65, 17-25. [CrossRef] 
12. Mastalerz, M.; Drobniak, A.; Filippelli, G. Mercury Content of Indiana Coals. In Research of Indiana Geological Survey; Indiana University: Bloomington, IN, USA, 2006.

13. Aleksa, H.; Dyduch, F.; Wiechowski, K. Chlor i rtęć w węglu i możliwości ich obniżenia metodami przeróbki mechanicznej. Górnictwo Geoinżynieria 2007, 31, 35-48.

14. Kolker, A.; Belkin, H.E. Characteristics of mercury-rich and extreme mercury-rich coals in the Donbas Region of Ukraine and Guizhou Province China. In Proceedings of the International Conference on Coal Science and Technology, Nottingham, UK, 28-31 August 2007.

15. Bukowski, Z.; Burczyk, A. Oznaczanie Rtęci w Węglach Koksujących. Analiza Korelacji; Konferencja Koksownictwo: Zakopane, Poland, 2008.

16. Wichliński, M.; Kobyłecki, R.; Bis, Z. The Investigation of Mercury Contents in Polish Coal Samples. Arch. Environ. Prot. 2013, 39, 141-150. [CrossRef]

17. Białecka, B.; Pyka, I. Rtẹć w Polskim Węglu Kamiennym do Celów Energetycznych i w Produktach Jego Przeróbki, 1; Główny Instytut Górnictwa Katowice: Katowice, Poland, 2016; pp. 1-167.

18. Baic, I.; Blaschke, W. Badania wstępne nad ograniczeniem zawartości rtęci w energetycznym węglu kamiennym poprzez zastosowanie wibracyjnego powietrznego stołu koncentracyjnego. Rocz. Ochr. Środowiska-Ann. Ual Set Environ. Prot. 2017, 19, 480-496.

19. Yudovich, Y.E.; Ketris, M.P. Mercury in coal: A review-Part 1. Geochemistry. Int. J. Coal Geol. 2005, 62, 107-134. [CrossRef]

20. Mastalerz, M.; Drobniak, A. Vertical variations of mercury in Pennsylvanian coal beds from Indiana. Int. J. Coal Geol. 2005, 63, 36-57. [CrossRef]

21. Klojzy-Karczmarczyk, B.; Mazurek, J. Studies of mercury content in selected coal seams of the Upper Silesian Coal Basin. Gospod. Surowcami Miner. Miner. Resour. Manag. 2013, 29, 95-106. [CrossRef]

22. Wierzchowski, K.; Chećko, J.; Pyka, I. Variability of Mercury Content in Coal Matter from Coal Seams of The Upper Silesia Coal Basin. Arch. Min. Sci. 2017, 62, 843-856. [CrossRef]

23. Strugała, A.; Makowska, D.; Bytnar, K.; Rozwadowska, T. Analysis of the contents of selected critical elements in waste from the hard coal cleaning process. Bull. Miner. Energy Econ. Res. Inst. Pol. Acad. Sci. 2014, 17, 77-88.

24. Ketris, M.; Yudovich, Y. Estimations of Clarkes for Carbonaceous biolithes: World averages for trace element contents in black shales and coals. Int. J. Coal Geol. 2009, 78, 135-148. [CrossRef]

25. Plewa, M. Igneous Rocks and Signs of Mineralization in the Western and Middle Part of the Wałbrzych Basin. In Prace Mineralogiczne PAN, 12; Wydawnictwo Geologiczne: Warsaw, Poland, 1968; pp. 1-64.

26. Morawiecki, A. Dickite and kaolinite veins (pholerites) from Nowa Ruda in Lower Silesia. Biul. Inst. Geol. 1956, 103, 5-38.

27. Kolker, A.; Panov, B.S.; Panov, Y.B.; Landa, E.R.; Conko, K.M.; Korchemagin, V.A.; Shendrik, T.; Mccord, J.D. Mercury and trace element contents of Donbas coals and associated mine water in the vicinity of Donetsk, Ukraine. Int. J. Coal Geol. 2009, 79, 83-91. [CrossRef]

28. Stryszewski, M. Eksploatacja Selektywna Węla Brunatnego Jako Metoda Ograniczenia Szkodliwego Oddziaływania na Środowisko Pierwiastków Obecnych w Węglu i Produktach Jego Spalania (Na Przykładzie KWB Bełchatów), 1; AGH: Crakow, Poland, 2001; pp. 1-144.

29. Słupczyński, K. The problem of genesis of natural gases collected in the Lower Permian formations. Zesz. Nauk. Politech. Śląskiej no. 865 (Górnictwo) 1987, 40, 39-48.

30. Озерова, Н.А. Ртуть и Эндогенное Рудообразование, 1; Наука: Moscow, Russia, 1986; pp. 86-103.

31. Finkelman, R.B. Modes of occurrence of trace elements in coal. Open-File Rep. 1981. [CrossRef]

32. O'Neil, B.T.; Tewalt, S.J.; Finkelman, R.B.; Akers, D.J. Mercury concentration in coal—Unraveling the puzzle. Fuel 1999, 78, 47-54.

33. Hower, J.C.; Campbell, J.L.; Teesdale, W.J.; Nejedly, Z.; Robertson, J.D. Scanning proton microprobe analysus of mercury and other trace element in Fe-sulfides from a Kentucky coal. Int. J. Coal Geol. 2008, 75, 88-92. [CrossRef]

34. Dziok, T.; Strugała, A.; Włodek, A. Studies on mercury occurrence in inorganic constituents of Polkish coking coals. Environ. Sci. Pollut. Res. 2019, 26, 8371-8382. [CrossRef] [PubMed]

35. Dziok, T.; Strugała, A.; Rozwadowski, A.; Macherzyński, M.; Ziomber, S. Rtęć w odpadach z procesów w zbogacania węgli kamiennych. Gospod. Surowcami Miner. Miner. Resour. Manag. 2015, 31, 107-122. [CrossRef]

36. Ruppert, L.F.; Hower, J.C.; Eble, C.F. Arsenic-bearing pyrite and marcasite ibn the Fire Clay coal bed, Middle Pennsylvanian Breathitt Formarion, eastern Kentucky. Int. J. Coal Geol. 2005, 63, 27-35. [CrossRef] 
37. Nieć, M.; Kurek, S.; Preidl, M. Zagadnienie dokumentowania zawartości pierwiastków śladowych w złożach węgli. Metod. Rozpoznawania Dok. Złóż Kopali Stałych 1990, 2, 185-190.

38. Finkelman, R.B. Mercury in coal and mercury emissions from coal combustion. In Geological Studies of Mercury by the U.S. Geological Survey; U.S. Geological Survey Circular: Denver, CO, USA, 2003; Volume 1248, pp. 9-11.

Publisher's Note: MDPI stays neutral with regard to jurisdictional claims in published maps and institutional affiliations.

(C) 2020 by the authors. Licensee MDPI, Basel, Switzerland. This article is an open access article distributed under the terms and conditions of the Creative Commons Attribution (CC BY) license (http://creativecommons.org/licenses/by/4.0/). 